\title{
THE DESIGN AND IMPLEMENTATION OF AN EDUCATIONAL MULTIMEDIA INTERACTIVE OPERATION SYSTEM USING LECTORA INSPIRE
}

\author{
Setya Chendra Wibawa, Rina Harimurti, Yeni Anistyasari \& Meini Sondang Sumbawati \\ Universitas Negeri Surabaya \\ e-mail: setyachendra@unesa.ac.id
}

\begin{abstract}
The objective this research to produce a valid interactive learning tool and practice based on learning media Lectora Inspire; knowing the student response against the learning tool, and knowing the student learning outcomes after using Lectora inspire learning media. Research and development of the research method using ADDIE model. Research with the learning media to be tested against the 32 student X level of Vocational High School and the subject is operation system. Research analysis results obtained through student response and question form reserved post-test. Validation of results obtained through validation by the validator which consists of one lecturer of Informatics and two teachers in a primary against $83.3 \%$ of Planning of Learning validation, validation against reserved posttest of $93.9 \%$ and validation against the media learner Lectora inspire of 100\%, the results of all the validations that meets the criteria for applied research. The percentage of the average student response against Lectora media inspire 85.9\%. While the percentage of student learning results expressed satisfaction with the presentation of graduation of $84.375 \%$ means it can be inferred that the media Lectora inspire gets good results and media can be said to be effective as a learning tool to supporting study students.
\end{abstract}

Keywords: ADDIE model, learning tool.

\section{INTRODUCTION}

The learning process in the development of science and technology increasingly encourages reform efforts in the utilization of the results of technology to improve student achievement (Grinager, 2006). The use of instructional media is one way that can be used by teachers to improve student learning. The use of instructional media is expected to help students understand and accept the learning process that teachers do. The conducted a systematic review to identify policy interventions that improve education quality and student learning in developing countries as suggestion that interventions are more effective at improving student performance and learning when social norms and intertemporal choices are factored in the design of education policies, and when two or more drivers of change are combined (Masino \& Zarazua, 2016).
Furthermore, it has been pointed out that there is often a disconnection between theory for designing educational applications and theory relating to the application of technology in the classroom (Offer, J., \& Bos, B. 2009). Teachers need to develop more methods Creative of learning and using the media to support the delivery of the operating system lesson. In the development of teaching methods will not be separated from the media. Media now have a lot used as a basis for proven media learning can complement and support the activities of interaction educators in learning activities.

This research explores the use of camera features on the cell phone to capture subjects in the creation of Javanese traditional wedding make up using the traditional costumes of each area and to document them using a cell phone with video camera features (Wibawa \& Schulte, 2014). 
The study reported in this paper addressed this disconnection and lack of alignment through the development of a strong educational framework and use of an appropriate instructional system design (ISD). The components of the framework are described in this article, followed by a discussion of the process of applying the defined instructional design principles to the creation of the My Maths Story project's interactive multimedia mathematics software. The entire implementation and evaluation process of the multimedia instructional materials, which targeted the teaching and learning of mathematics in the lower primary classrooms, is also presented (Moradmand., Datta, A. \& Oakley, G., 2014).

One of them is LectoraInspire, that an effective program to make learning media (Faruk, 2014). Lectora Inspire is a software development of electronic learning (elearning) is relatively easy to apply or implement because it does not require a sophisticated understanding of programming languages.

Because of Lectora Inspire interfaces familiar to us who have known and mastering Microsoft Office. Use of the Lectora subject matter operating systems designed and built some of the slides also show videos associated with the operating system, as well as animated images that relate to the subject matter the operating system so that students pay more attention to what is conveyed by the teacher. This, of course, will affect student learning. Many students assume that learning is boring, something similar happened to students.

The study was to investigate the effects of here and now mobile learning on student achievement and attitude. Participants took a pretest at the beginning of the study and then were assigned to one of the versions of an art lesson (CBI version and $\mathrm{iPad} / \mathrm{iPod}$ version) which were developed using Lectora Inspire incorporating information on five different paintings in the education building. After the lesson, they completed the posttest and an attitude survey (Martin \& Ertzberger, 2013: 76-85).

\section{METHODS}

The method of development using ADDIE model, which is one of the systematic instructional design models. According to Dick, W \& Carey, L., ADDIE models consist of five steps: (1) analyze; (2) design; (3) development; (4) implementation; and (5) evaluation.

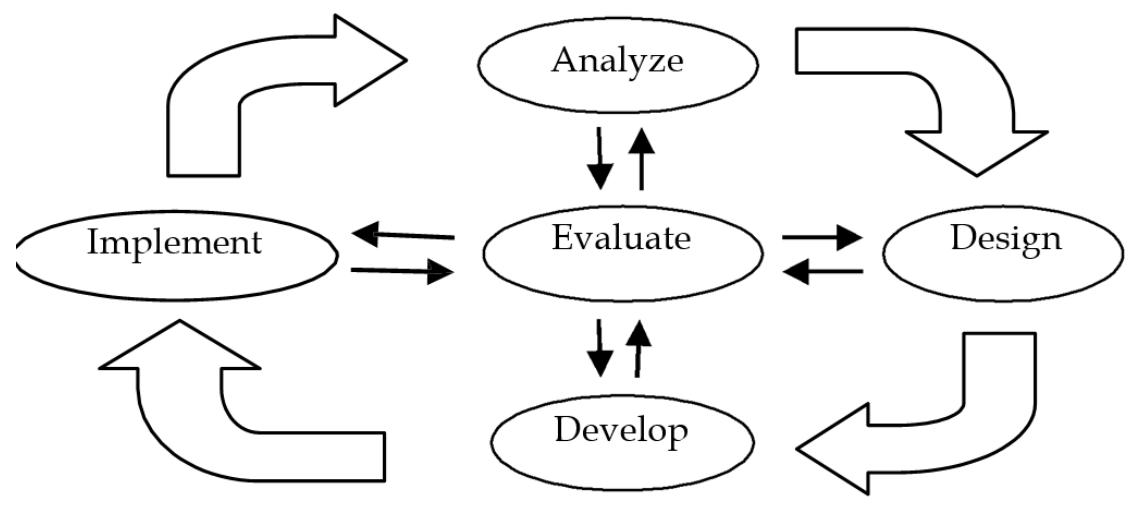

Figure 1. ADDIE model (Dick \& Carey 1996) 
The analysis conducted to obtain information on the competencies required learners. Analyzing about how learning, knowledge and attitudes of learners. Conducting analyzes related to competence or materials used in school, to know the characteristics of the learners who will be next targeted learning media.

The process of designing a model/design phase of this learning method has two stages of the design is the first to design teaching and learning. This activity is a systematic process that begins and establish learning objectives, designing storyboard or tutoring, designing a learning device (the media), to design learning materials and tools evaluation of learning outcomes. For the second draft is a draft in the form of instructional media which researchers design a media application using Lectora Inspire. Once the design process is complete media will further media show to the supervisor for validation before hand whether the media is feasible to use media as research. The design of instructional media that has been validated is still conceptual in other words not perfect because it has not been tested directly in the process of further research. Once the material is delivered with instructional media were then students or learners will be given a sheet assessment questionnaire for the assessment of the media that has been given, figure 2 shows the flow of Media.

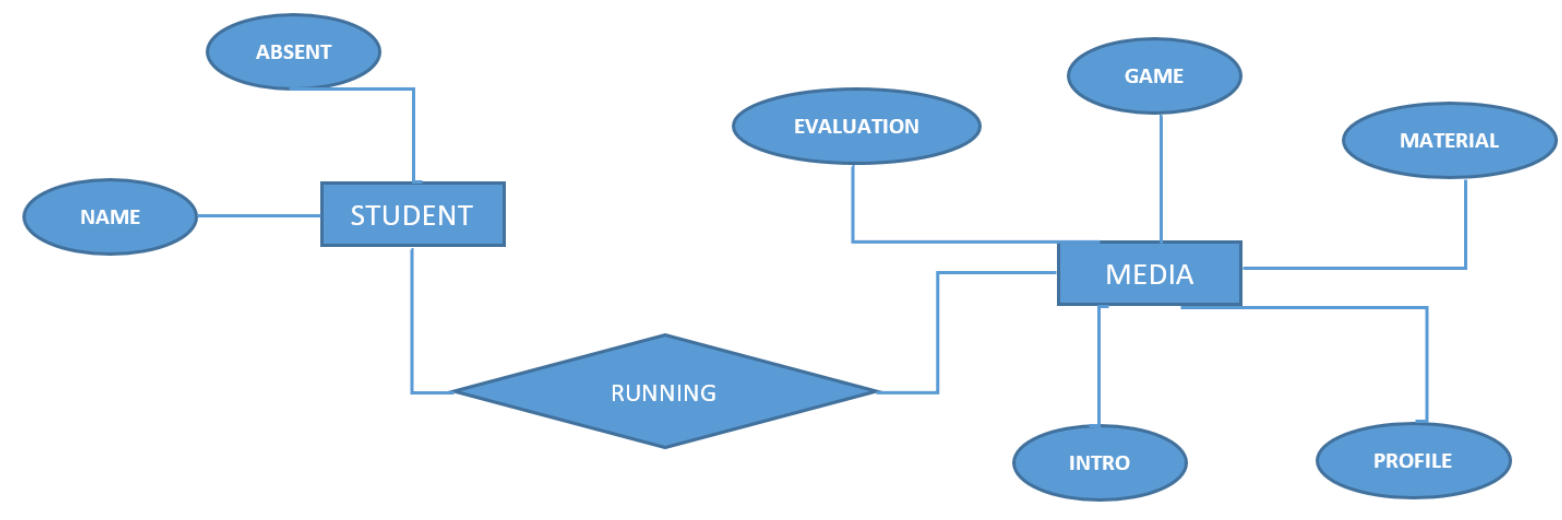

Figure 2. ERD media

The context of the development of teaching materials (books or modules, development stage do by examining the content and legibility of the modules or textbooks that the supervisor to obtain validation of the draft media. To determine the effectiveness of the media in improving learning outcomes of activities followed by members practice questions that the material is taken from the media.

This stage the implemented design and methods have been developed in a real situation that is in the classroom. During the implementation of the draft media that has been developed applied to the condition that actually. The subject matter is delivered in accordance with the media developed. After the adoption of the media then conducted an initial evaluation for member feedback on the implementation of the media to determine the impact on the quality of learning that includes effectiveness and efficiency of learning for students.

The evaluating done in two forms: a formative and summative evaluation. A formative evaluation conducted at the end-face whereas summative evaluation is done after the intervention ended. Evaluation summative measuring end of the competence of subjects or objectives learning. The result of the evaluation is used to provide feedback to the users. Revision made in accordance with the 
results evaluation or needs that can not be filled with these methods.

\section{RESULTS}

In this study, validation of data obtained from three validators consisting of one faculty of the Informatics State University of Surabaya and two teachers of Vocational High
School. The results of learning media, learning the resulting product is learning Lectora inspire media. This learning media has content in the form of quiz exercises, materials, library. Here's one example of the content Exercises When students have completed all or some of the items will display the final value as follows:

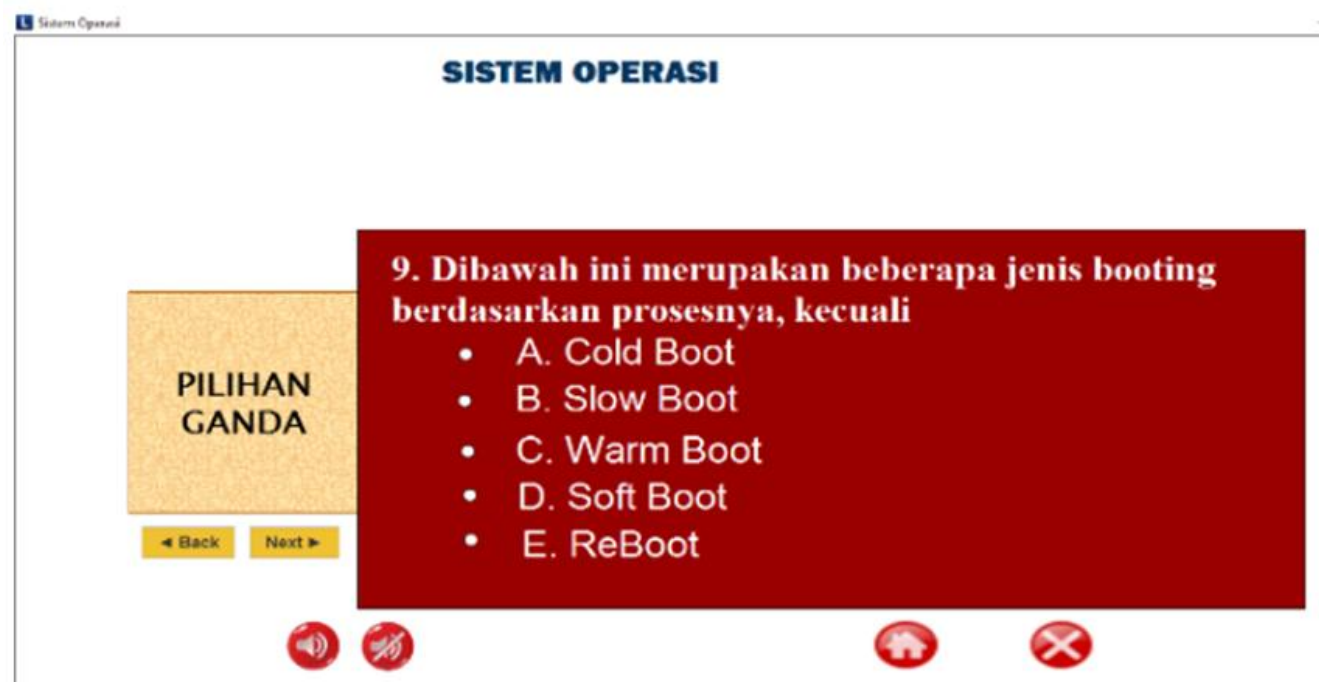

Figure 3. Page of multiple choice of question

Results Validation of the three validators shows media Lectora inspire the design aspects of the media gets a percentage of $97.22 \%$ which indicates that aspects into the category of very valid. In the aspect of media content received $94.44 \%$ included in the category valid.

In the aspect of language gets a percentage of $95.83 \%$ is included in the category of very valid. Validation results about the media in a material aspect gets a percentage of $91.7 \%$, the construction aspect gets a percentage of $90.0 \%$ and aspects of language get a percentage of $100 \%$. The total of the results of the validation problem gets a percentage of $93.9 \%$, which is included in the category of very valid.

Then to the average value of the Planning of Learning (RPP) validation get a percentage of $88.2 \%$ which is included in the excellent category.

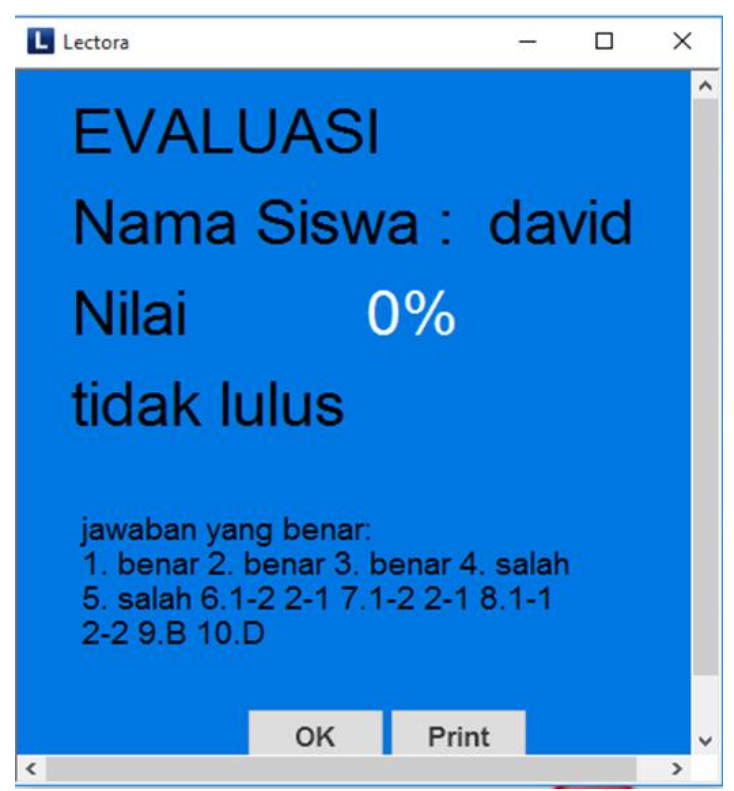

Figure 4. Outcome of evaluation

Learning Results obtained during the test phase media. Lectora Inspire held 2 meetings, namely one at KD 3.3 and two times at KD 4.3. The first meeting at KD 3.3 and 4.3 
each student explained about the boot manager on the media Lectora Inspire. The second and third meetings of learning KD 3.3 and 4.3 implemented with $2 \times 45$ minute time allocation. The teacher explains briefly or does a review of the previous lesson. Student learning outcomes in this study can provide questions post-test that have previously been validated. Numbering about 20 items in the form of multiple choice. Students who are 32 students the following study. Students are said to be complete if the minimum score obtained to achieve a range of values 3.0-3,5

$$
\text { Student Value }=\frac{\text { Score }}{\text { Maximum Score }} \times 4
$$

Results of a table known value of students who have used the learning Lectora Inspire and learning outcomes provisions completeness percentage as follows:

$$
P=\frac{\text { Score }}{\text { Student Totally }} \times 4
$$

From the data already collected convertible note that Graduate students who use the media Lectora inspire for $84.375 \%$ declared complete and the students who did not complete $15.625 \%$ means it can be concluded that media inspire Lectora got good results and media can be said to be effective as a self-supporting student learning.

\section{CONCLUSION}

Based on results, the interactive learning tool has been reviewed by the expert and some suggestion from them have been conducted to get the better tool. The interactive learning tool have significant effects to increase the student learning outcome. It showed by results and can be concluded that: (1) The ADDIE model was found to be a useful guideline for building effective teaching and learning as tools of instructional design; (2) The results of student responses based on questionnaires that have previously been tested to 32 students $\mathrm{X}$ level of Vocational High School get results overall student response get a percentage of $85.9 \%$, which is included in the category of good, it mean percentage indicate responses positive from students to learning tool Lectora Inspire used as a medium of learning on the subjects of the operating system; and (3) The application base on Lectora Inspire can be used by student as Learning too.

\section{REFERENCES}

Dick, W., \& Carey, L. 1996. The systematic design of instruction (4th ed.). New York: Harper Collins College Publishers

Faruk, Alfensi. 2014. Development of Interactive Learning Media Based Lectora Inspire in Discrete Method Course. Proceeding of International Conference On Research Implementation and Education of Mathematics and Sciences. ISBN: 9780979-99314-8-1

Grinager, Heather. 2006. How Education Technology Leads to Improved Student Achievement. National Conference of State Legislatures. Education Issues.

Masino, Serena and Zarazua, Miguel Nino. 2016. What Works to Improve The Quality of Student Learning in Developing Countries?. International Journal of Educational Development. Volumen 48 Pages 53-65.

Martin, Florence and Ertzberger, Jeffrey. 2013. Here and Now Mobile Learning : An Experimental Study on The Use of Mobile Technology. Journal Computers and Education Pages 76-85.

Moradmand, Nasrin; Datta, Amitava and Oakley, Grace. 2014.The Design and Implementation of an Educational Multimedia Mathematics Software: Using ADDIE to Guide Instructional System Design .The Journal of Applied Instructional Design, Vol 4 Issue 1 
October. http://jaidpub.org ISSN: 2160-5289

Offer, J., \& Bos, B. 2009. The design and application of technology-based courses in the mathematics classroom. Computers \& Education, 53(4), 11331137

Wibawa, Setya Chendra., \& Beth Clark. 2014. The Value of Student Creative ePortfolio Using Android Cellphone Cameras for Inventive Beauty
Photography. International Conference on Advanes in Education Technology (ICAET), ISBN: 978-94-62520-44-8, ISSN:2352-5398, http://www.atlantispress.com/php/download_paper.php?id= 16161

Wibawa, Setya Chendra, Schulte, Svan, 2015. Beauty Media Learning using Android Mobile Phone. http://ijirae.com/volume2-issue-11 page 20-26 